\title{
CORRIGENDUM
}

\section{Insulin resistance in young, lean male subjects with essential hypertension}

\author{
A Penesova, E Cizmarova, V Belan, P Blazicek, R Imrich, M Vlcek, M Vigas, D Selko, J Koska and Z Radikova
}

Journal of Human Hypertension (2014) 28, 212; doi:10.1038/jhh.2013.114

Correction to: Journal of Human Hypertension (2011) 25, 391-400; 10.1038/jhh.2010.72; published online 15 July 2010

Post publication, the authors noticed that one of the grant numbers in their Acknowledgements section was incorrect. The corrected Acknowledgements section appears here.

The authors would like to apologise for their error.

\section{ACKNOWLEDGEMENTS}

This study was supported by Grants VEGA 2/0154/10, MZ 2007/27-SAV-02 and CENDO SAV. We thank Mrs Emilia Andelova for her excellent technical assistance. 